\title{
梁ウェブにおけるモーメント伝達効率が低い柱梁接合部の 繰り返し載荷実験
}

\section{CYCLIC LOADING TEST OF BEAM-TO-COLUMN CONNECTION WITH LOW MOMENT TRANSFERRING EFFICIENCY IN WEB}

\author{
山田哲*1, 三木徳人*2, 吉敷祥 一 ${ }^{* 3}$, 長谷川 隆*4, 焦 瑜 ${ }^{* 5}$ \\ Satoshi YAMADA, Norihito MIKI, Shoichi KISHIKI, \\ Takashi HASEGAWA and Yu JIAO
}

\begin{abstract}
When SN490 beam is connected to BCR295 column, especially when the joint efficiency at beam web is low, there is a high possibility that the connection does not meet the joint coefficient criteria of connection strength. A comprehensive evaluation of the plastic deformation capacity of these connections is necessary. Nineteen beam-to-column specimens with joint coefficients ranged from 0.97 to 1.39 were tested under incremental cyclic loadings. The plastic deformation capacity, maximum strength, yield strength and full plastic strength of the specimens with different failure modes were evaluated quantitatively. The test results show that for the specimens with low joint coefficients, although the plastic deformation capacities are not particularly good, these specimens reached the minimum requirements of seismic design. The test results also indicate that the "Recommendation for Design of Connections in Steel Structures" provides accurate evaluation of both the maximum strength of beam-to-column connections and joint efficiency on the safe side.
\end{abstract}

keywords: beam-to-column connection, plastic deformation capacity, cyclic loading test, fracture 柱梁接合部，塑性変形能力，繰り返し載荷実験，破断

\section{1. 序}

柱を角形鋼管とした柱梁接合部では、梁ウェブから柱へのモーメ ント伝達は柱のスキンプレートを介して行われるが、スキンプレー トが面外に変形することから、特に柱板厚が薄い場合にはスキンプ レートの面外剛性および而力が不足し梁ウェブにおけるモーメント 伝達効率が低下寸る。日本建築学会鋼構造接合部設計指針 ')(以降、 接合部設計指針)には、極限解析に基づく梁ウェブのモーメント伝 達効率を考慮した接合部の最大耐力の算定法が示されており、柱と 梁の断面および鋼種の組み合わせ、スカラップの有無を考慮して、 接合部の最大耐力を評価することができる。

梁ウェブにおけるモーメント伝達効率を考慮した接合部の最大耐 力の評価結果としては、日本建築学会溶接接合設計施工ガイドブッ ク ${ }^{2}$ に、BCR295 である角形鋼管柱と JIS 細幅系列の梁断面の組み 合わせごとの、接合部の最大耐力の梁の全塑性耐力に対する比率で ある接合部係数が示されており、梁を SN490 とした場合には SN400 とした場合に比べ多くの組み合わせで接合部係数が塑性変形能力を 確保するための保有耐力接合の条件 ")を満足しないとされている。
ここで、接合部設計指針 ${ }^{11}$ では、梁を SN490 とした場合の保有耐力 接合の条件として、鋼材の強度のばらつきなどに基づき接合部係数 で 1.25 以上確保することとしている。一方、文献 3)では、梁を SN490 とした場合の保有耐力接合の条件として接合部係数で 1.2 としてい るが、この条件で判定した場合においても、保有耐力接合の条件を 満足しない断面の組み合わせがでてくる。

汎用的な部材断面の組み合わせで接合部係数が低くなる場合が多 いことから、接合部係数が低くなった場合には接合部の破断(本研 究では延性破断を対象とする)によって決まる梁の塑性変形能力が どの程度となるかを調べておくことは重要な課題であるが、既往の 梁端接合部に関する実験では比較的接合部係数が大きな試験体が扱 われていることが多く付䟿 !、梁ウェブにおけるモーメント伝達効率 が低く接合部係数の低い場合にどの程度の変形性能力があるについ ては、十分わかっていない。本研究ではまず、梁ウェブにおけるモ ーメント伝達効率が低いことで接合部係数が低くなった梁端接合部 について、接合部係数と変形能力の関係を定量的に把握することを 目的に、接合部を含む部分架構の繰り返し載荷実験を行う。
*1 東京工業大学建築物理研究センター 教授・博士 (工学)

*2 東京工業大学 大学院生・修士 (工学)

*3 東京工業大学建築物理研究センター 准教授・博士 (工学)

*4 建築研究所構造研究グループ 主任研究員・博士 (工学)

*5 東京理科大学工学部建築学科 助教. 博士 (工学)
Prof, Structural Engineering Research Center, Tokyo Tech, Dr.Eng. Grad. Stud., Tokyo Tech., M.Eng.

Assoc. Prof., Structural Engineering Research Center, Tokyo Tech., Dr.Eng.

Senior Researcher, Structural Engineering Dept., Building Research Institute, Dr.Eng. Assist. Prof., Dept. of Architecture, Tokyo Univ. of Science, Dr.Eng. 


\section{2. 実験概要}

\section{1 試験体}

試験体一覧を表 1 に、形状を図 1 に、素材試験結果の一覧を表 2 に示寸。実験は梁ウェブにおけるモーメント伝達効率をパラメータ ーとして、16 体の試験体に対して 2 シリーズに分けて行った。ま た、既報 ${ }^{4} に お け る$ 梁ウェブにおけるモーメント伝達効率の低い試 験体 3 体(No.17 19_接合部における偏心無し)についても検討に加 えることにし、表中に併せて示している。

第 1 シリーズ(No.1 10)は、試験体は通しダイアフラム形式の角 形鋼管柱- $\mathrm{H}$ 形鋼梁接合部、もしくは $\mathrm{H}$ 形鋼梁の端部をエンドプレ 一トに溶接する形式の接合部とする 10 体の試験体により構成され る。試験体のパラメーターは、梁ウェブにおけるモーメント伝達効 率の低下の要因となる柱板厚とスカラップの有無、ならびに局部座 屈の発生を抑えるための梁端のスチフナの有無である。梁は同一ロ ットの H-600×200×11×17(SN490B：フランジ FA，ウェブ FB)、柱は 幅 $400 \mathrm{~mm}$ で板厚 $12 \mathrm{~mm}$ と $19 \mathrm{~mm}$ の角形鋼管(BCR295) とした。実験 計画段階では、接合部の最大耐力 ${ }_{j} M u$ (計算值 $)^{1)}$ の梁の全塑性耐力 ${ }_{b} M_{P}$ (計算值 $)$ に対する比率で定義される接合部係数が 1.2 前後となる ように、引張強さおよび降伏点の規格下限值と公称板厚を用いて計 算した接合部係数 $\alpha_{F}$ で 1.14 1.33 の範囲となるよう断面の組み合 わせを決めたが、実際には梁フランジの降伏比が 0.627 と低かった ことから、素材試験結果と実測板厚を用いて求めた接合部係数 $\alpha$ は 1.19 1.39 と、実験計画より高くなった。降伏比が接合部係数に 与える影響については、付録 2 に示寸。

第 2 シリーズ(No.11 16)においても、試験体は通しダイアフラム 形式の角形鋼管柱-H 形鋼梁接合部としたが、梁断面は梁ウェブに おけるモーメント伝達効率の影響が大きくなるように梁ウェブの板 厚を厚くした溶接組立部材 BH- $600 \times 200 \times 16 \times 16 、 B H-600 \times 200 \times 12 \times 16$ (いずれも SN490B : フランジFA， ウェブ FA)とし、柱は幅 $400 \mathrm{~mm}$ で板厚 $12 \mathrm{~mm}, 16 \mathrm{~mm}, 19 \mathrm{~mm}$ の角形鋼管(BCR295)として、これらの断 面の組み合わせの 6 体とした。第 2 シリーズでは全ての試験体でス カラップ有りの接合部詳細とし、局部座屈の発生を抑えるためのス チフナを設置した。第 2 シリーズの試験体について、引張強さおよ び降伏点の規格下限值と公称板厚を用いて計算した接合部係数 $\alpha_{F}$ は 1.02 1.21 の範囲であったが、素材試験結果と実測板厚を用いて 求めた接合部係数 $\alpha$ は 0.97 1.15 と、こちらは計画より低くなった。

既報 ${ }^{4)}$ の実験では、梁を H-500 × 200(No.17 では 150)× $10 \times$ 16(SN490B：フランジ FA，ウェブ FA)、柱を幅 $300 \mathrm{~mm}$ で板厚 $9 \mathrm{~mm}, 12 \mathrm{~mm}$ の角形鋼管(BCR295)とした 3 体の試験体を用いた。い ずれの試験体もスカラップ有りの接合部詳細とし、局部座屈の発生 を抑えるためのスチフナを設置した。これらの試験体の素材試験結 果と実測板厚を用いて求めた接合部係数 $\alpha$ は 1.08 1.19 である。

なお、全ての試験体共通で、梁端接合部の溶接ではエンドタブは 固形タブを使用した。また、通しダイアフラム形式の試験体ではダ イアフラムの板厚を $22 \mathrm{~mm}$ とし、スカラップ有りの試験体ではス カラップの形状を JASS6 準拠の複合円タイプとした。局部座屈の 発生を抑えるためのスチフナを設置した試験体では、第 1 第 2 シ リーズ(No.1 16)については、板厚 9mm のスチフナを柱フェィスか ら 120,220,320mm の位置に配し、既報 ${ }^{4}$ の実験で用いた試験体(No.17 〜 19)では、柱フェイスから 100,200,300mm の位置に配した。

\section{2 載荷方法}

セットアップを図 2 に示す。試験体は柱を水平に、梁を鉛直にし た状態で反カフレームに固定し、梁先端にオイルジャッキを取り付 けて載荷を行った。柱端部では、PC 鋼棒で鉛直方向の反力を、ス クリュージャッキで水平方向の反力をとった。梁の面外変形及びね じれ変形に対しては加力点に板ピンを取り付け、接合部近傍と加力 点近傍では試験体との間にテフロンシートを挟んだ溝形鋼で挟み込 むことで拘束した。

載荷履歷を図 3 に示す。文献 5)で提案された載荷履歴を用い、 全塑性耐力に対応する弾性変形を ${ }_{b} \theta_{p}$ として、2 サイクル毎の変位 振幅増分を $2_{b} \theta_{p}$ とした載荷を行った。

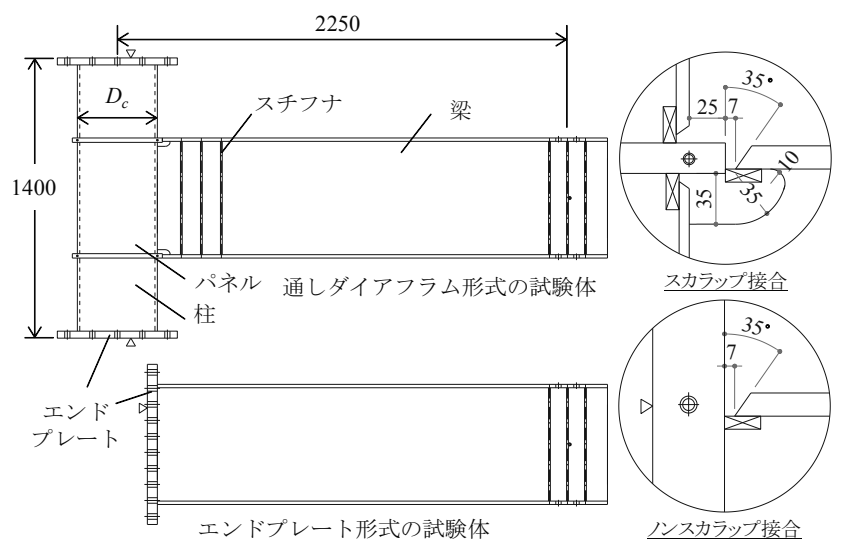

図1 試験体形状

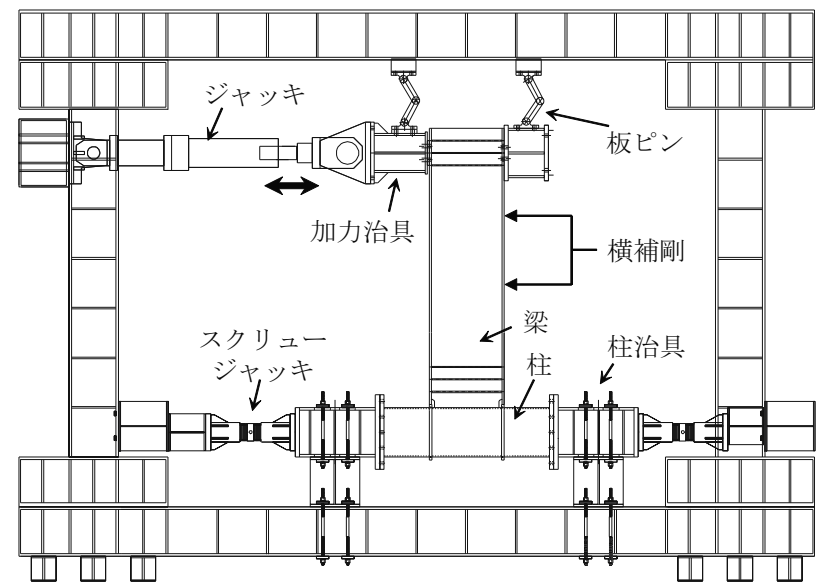

図2 セットアップ

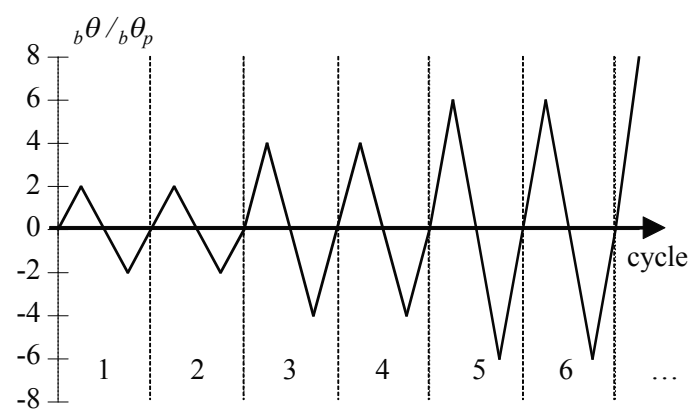

図3 載荷履歴 
表 1 試験体一覧

\begin{tabular}{|c|c|c|c|c|c|c|c|c|c|c|c|c|c|c|c|c|}
\hline \multirow{2}{*}{ No. } & \multirow{2}{*}{ 試験体名 } & \multicolumn{2}{|c|}{ 部材断面 } & \multirow{2}{*}{ スカラップ } & \multirow{2}{*}{ スチフナ } & \multirow{2}{*}{$\begin{array}{c}l_{b} \\
(\mathrm{~mm})\end{array}$} & \multirow{2}{*}{$\begin{array}{c}{ }_{b M_{p}} \\
(\mathrm{kN} \cdot \mathrm{m})\end{array}$} & \multirow{2}{*}{$\begin{array}{c}{ }_{j u} \\
(\mathrm{kN} \cdot \mathrm{m}) \\
\end{array}$} & \multirow{2}{*}{$\alpha$} & \multirow{2}{*}{$m$} & \multirow{2}{*}{$\alpha_{F}$} & \multirow{2}{*}{$m_{F}$} & \multirow{2}{*}{\begin{tabular}{|c|}
${ }_{j} M_{w u}$ \\
$(\mathrm{kN} \cdot \mathrm{m})$ \\
\end{tabular}} & \multirow{2}{*}{$\begin{array}{c}{ }_{j} M_{f u} \\
(\mathrm{kN} \cdot \mathrm{m})\end{array}$} & \multirow{2}{*}{\begin{tabular}{|c|}
${ }_{j} M_{y}$ \\
$(\mathrm{kN} \cdot \mathrm{m})$ \\
\end{tabular}} & \multirow{2}{*}{$\begin{array}{c}{ }_{j} M_{p} \\
(\mathrm{kN} \cdot \mathrm{m})\end{array}$} \\
\hline & & 梁 & 柱 & & & & & & & & & & & & & \\
\hline 1 & A-12 & $\mathrm{H}-600 \times 200 \times 11 \times 17$ & $\square-400 \times 400 \times 12$ & 有 & 有 & 2,050 & 979 & 1,162 & 1.19 & 0.49 & 1.14 & 0.48 & 125 & 1,037 & 680 & 775 \\
\hline 2 & A-19 & $\mathrm{H}-600 \times 200 \times 11 \times 17$ & $\square-400 \times 400 \times 19$ & 有 & 有 & 2,050 & 979 & 1,235 & 1.26 & .78 & 1.20 & .74 & 198 & 1,037 & 727 & 848 \\
\hline 3 & A-F & $\mathrm{H}-600 \times 200 \times 11 \times 17$ & & 有 & 有 & 2,050 & 979 & 1,290 & 1.32 & 1.00 & 1.26 & 1.00 & 253 & 037 & 751 & 903 \\
\hline 4 & B-12 & H- $600 \times 200 \times 11 \times 17$ & $\square-400 \times 400 \times 12$ & 無 & 有 & 2,050 & 979 & 1,200 & 1.23 & 0.49 & 1.18 & 0.48 & 163 & 1,037 & 738 & 813 \\
\hline 5 & B-19 & $\mathrm{H}-600 \times 200 \times 11 \times 17$ & $\square-400 \times 400 \times 19$ & $\begin{array}{l}\text { 無 } \\
\end{array}$ & 有 & 2,050 & 979 & 1,295 & 1.32 & 0.78 & 1.26 & 0.74 & 258 & 1,037 & 785 & 908 \\
\hline 6 & C-12 & $\mathrm{H}-600 \times 200 \times 11 \times 17$ & $\square-400 \times 400 \times 12$ & 有 & 無 & 2,050 & 979 & 1,162 & 1.19 & 0.49 & 1.14 & 0.48 & 125 & 1,037 & 680 & 775 \\
\hline 7 & C-19 & $\mathrm{H}-600 \times 200 \times 11 \times 17$ & $\square-400 \times 400 \times 19$ & 有 & 無 & 2,050 & 979 & 1,235 & 1.26 & 0.78 & 1.20 & 0.74 & 198 & 1,037 & 727 & 848 \\
\hline 8 & D-12 & $\mathrm{H}-600 \times 200 \times 11 \times 17$ & $\square-400 \times 400 \times 12$ & 無 & 無 & 2,050 & 979 & 1,200 & 1.23 & 0.49 & 1.18 & 0.48 & 163 & 1,037 & 738 & 813 \\
\hline 9 & D-19 & $\mathrm{H}-600 \times 200 \times 11 \times 17$ & $\square-400 \times 400 \times 19$ & 無 & 無 & 2,050 & 979 & 1,295 & 1.32 & 0.78 & 1.26 & 0.74 & 258 & 1,037 & 785 & 908 \\
\hline 10 & D-F & $\mathrm{H}-600 \times 200 \times 11 \times 17$ & PL50*) & 無 & $\begin{array}{l}\text { 無 } \\
\end{array}$ & 2,050 & 979 & 1,366 & 1.39 & 1.00 & 1.33 & 1.00 & 329 & 1,037 & 809 & 979 \\
\hline 11 & BH16-12 & $\mathrm{H}-600 \times 200 \times 16 \times 16$ & $\square-400 \times 400 \times 12$ & 有 & 有 & 2,050 & 1,144 & 1,111 & 0.97 & 0.43 & 1.02 & 0.39 & 155 & 957 & 720 & 831 \\
\hline 12 & BH16-16 & H- $600 \times 200 \times 16 \times 16$ & $\square-400 \times 400 \times 16$ & 有 & 有 & 2,050 & 1,144 & 1,162 & 1.02 & 0.5 & 1.06 & 0.52 & 205 & 95 & 762 & 881 \\
\hline 13 & BH16-22 & $\mathrm{H}-600 \times 200 \times 16 \times 16$ & $\square-400 \times 400 \times 22$ & 有 & 有 & 2,050 & 1,1 & 1,235 & 1.0 & 0. & 1. & 0.70 & 27 & 95 & 817 & 955 \\
\hline 14 & BH12-12 & $\mathrm{H}-600 \times 200 \times 12 \times 16$ & $\square-400 \times 400 \times 12$ & 有 & 有 & 2,050 & 1,042 & 1,094 & 1.0 & 0.49 & 1.11 & 0.46 & 13 & 957 & 719 & 813 \\
\hline 15 & BH12-16 & $\mathrm{H}-600 \times 200 \times 12 \times 16$ & $\square-400 \times 400 \times 16$ & 有 & 有 & 2,050 & 1,042 & 1,138 & 1.09 & 0.64 & 1.15 & 0.60 & 18 & 95 & 753 & 858 \\
\hline 16 & BH12-22 & $\mathrm{H}-600 \times 200 \times 12 \times 16$ & $\square-400 \times 400 \times 22$ & 有 & 有 & 2,050 & 1,042 & 1,203 & 1.15 & 0.88 & 1.21 & 0.81 & 24 & 957 & 796 & 923 \\
\hline 17 & \begin{tabular}{|l|} 
C- $150-9$ \\
\end{tabular} & $\mathrm{H}-500 \times 150 \times 10 \times 16$ & $\square-300 \times 300 \times 9$ & 有 & 有 & 2,100 & 612 & 663 & 1.08 & 0.41 & 1.09 & 0.39 & 63 & 600 & 404 & 464 \\
\hline 18 & C-200-12 & $\mathrm{H}-500 \times 200 \times 10 \times 16$ & $\square-300 \times 300 \times 12$ & 有 & 有 & 2,100 & 745 & 886 & 1.19 & 0.56 & 1.19 & 0.52 & 85 & 800 & 552 & 619 \\
\hline 19 & \begin{tabular}{|l|}
$C-200-9$ \\
\end{tabular} & $\mathrm{H}-500 \times 200 \times 10 \times 16$ & $\square-300 \times 300 \times 9$ & 有 & 有 & 2,100 & 745 & 863 & 1.16 & 0.41 & 1.17 & 0.39 & 63 & 800 & 533 & 597 \\
\hline
\end{tabular}

表中、 $l_{b}$ : 梁の曲げ長さ, ${ }_{b} M_{p}$ : 梁の全塑性耐力の計算値, ${ }_{j} M_{u}$ : 梁端接合部の最大曲げ耐力の計算値, $\alpha$ : 接合部係数 $\left(={ }_{j} M_{u} / b M_{p}\right), m:$ 梁ウェブ接 合部の無次元化曲げ耐力, $\alpha_{F}$ : 鋼材の規格強度の下限值と公称板厚を用いて計算した接合部係数, $m_{F}$ : 鋼材の規格強度の下限值と公称板厚を 用いて計算した梁ウェブ接合部の無次元化曲げ耐力, ${ }_{j} M_{w u}$ : 梁ウェブ接合部の最大曲げ耐力の計算值( 3.3 節), ${ }_{j} M_{f u}$ : 梁フランジ接合部の最大曲 げ耐力の計算值(3.3 節), ${ }_{j} M_{y}$ : 接合部の降伏耐力の計算值(3.4 節), ${ }_{j} M_{p}$ : 接合部の全塑性耐力の計算值(3.4 節)

\section{表2 素材試験結果一覧}

\begin{tabular}{|c|c|c|c|c|c|c|c|c|}
\hline & & & 鋼種 & \begin{tabular}{|c|} 
実測板厚 \\
$(\mathrm{mm})$
\end{tabular} & $\begin{array}{l}\text { 降伏点*1 } \\
\left(\mathrm{N} / \mathrm{mm}^{2}\right)\end{array}$ & $\begin{array}{l}\text { 引張強さ } \\
\left(\mathrm{N} / \mathrm{mm}^{2}\right)\end{array}$ & $\begin{array}{c}\text { 降伏比 } \\
(\%)\end{array}$ & $\begin{array}{c}\mid \begin{array}{c}\text { 破断伸び } \\
(\%)\end{array} \\
\end{array}$ \\
\hline \multirow{4}{*}{$\begin{array}{l}\text { No. } 1 \\
\sim 10\end{array}$} & \multirow{2}{*}{ | } & フランジ & SN490B & 17.1 & 326 & 520 & 62.7 & 30.7 \\
\hline & & ウェブ & SN490B & 10.8 & 381 & 553 & 68.9 & 26.0 \\
\hline & \multirow{2}{*}{ |杜 } & $\square-400 \times 400 \times 12$ & BCR295 & 12.0 & 366 & 447 & 81.9 & 29.2 \\
\hline & & $\square-400 \times 400 \times 19$ & BCR295 & 19.1 & 377 & 417 & 90.4 & 29.3 \\
\hline \multirow{5}{*}{$\begin{array}{l}\text { No.11 } \\
\sim 16\end{array}$} & \multirow{2}{*}{ | } & PL-16 & SN490B & 15.9 & 364 & 515 & 70.7 & 28.9 \\
\hline & & PL-12 & SN490B & 12.1 & 375 & 530 & 70.8 & 25.7 \\
\hline & & $\square-400 \times 400 \times 12$ & BCR295 & 12.3 & 374 & 444 & 84.2 & 27.1 \\
\hline & 柱 & $\square-400 \times 400 \times 16$ & BCR295 & 16.4 & 377 & 444 & 84.9 & 27.9 \\
\hline & & $\square-400 \times 400 \times 22$ & BCR295 & 22.4 & 385 & 436 & 88.3 & 28.6 \\
\hline \multirow{4}{*}{$\begin{array}{r}\text { No.17 } \\
\sim 19\end{array}$} & \multirow[b]{2}{*}{ 梁 } & フランジ & SN490B & 15.8 & 349 & 523 & 66.7 & 27.8 \\
\hline & & ウェブ & SN490B & 9.9 & 389 & 530 & 73.4 & 26.9 \\
\hline & \multirow{2}{*}{ 枉 } & $\square-300 \times 300 \times 9$ & BCR295 & 8.9 & 394 & 472 & 83.5 & 23.0 \\
\hline & & $\square-300 \times 300 \times 12$ & BCR295 & 11.8 & 417 & 487 & 85.6 & 27.9 \\
\hline
\end{tabular}

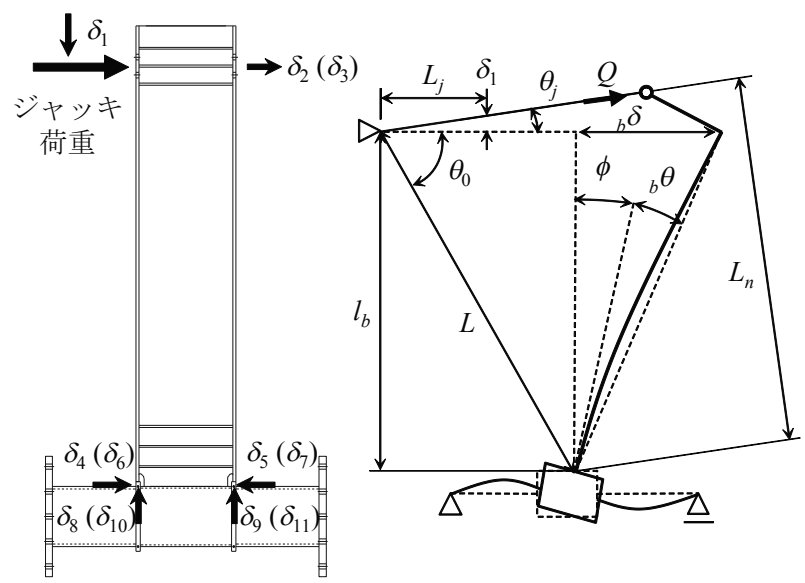

図4 荷重と変形の計測

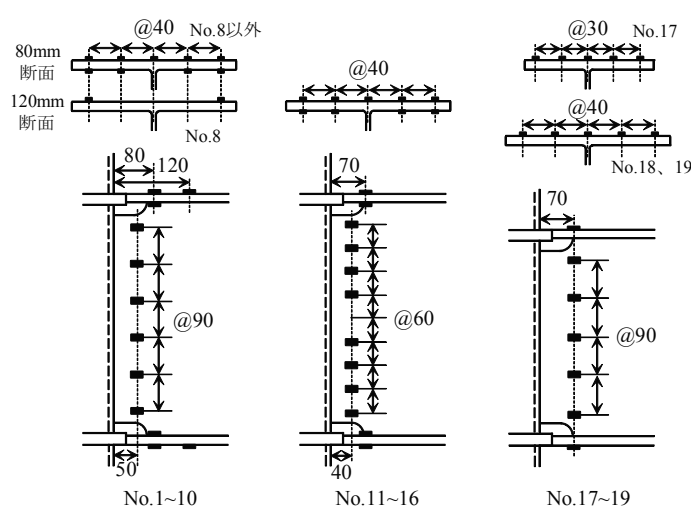

図5 梁端におけるフランジとウェブの歪計測位置 $(\mathrm{mm})$

\section{3 計測方法}

試験体の変形は、図 4 に示す位置に設置した変位計により計測し、 試験体に作用するせん断力は、ジャッキ先端に組み込まれたロード セルにより計測した。図 4 中、 $\delta$ 1 はジャッキの鉛直変位、 $\delta_{2} 、 \delta_{3}$ は 加力点の水平変位、 $\delta_{4}, \delta_{5}, \delta_{6}, \delta_{7}$ は柱フェイス面における梁フラ ンジ中心線での水平変位、 $\delta 8 、 \delta_{9} 、 \delta_{10} 、 \delta_{11}$ は鉛直変位である。図中、 括弧が無いものは紙面表側の変位計測值、有るものは裏側の変位計 測值である。これらの変位及び荷重の計測值より、梁端モーメント ${ }_{b} M$ 、梁の部材角 ${ }_{b} \theta$ を式(1) (6)により算出した。

$$
\begin{aligned}
& { }_{b} M=Q \cdot L_{n} \\
& L_{n}=L \cdot \sin \left(\theta_{0}+\theta_{j}\right) \\
& \theta_{j}=\delta_{1} / L_{j}
\end{aligned}
$$




$$
\begin{aligned}
& { }_{b} \theta=\frac{{ }_{b} \delta}{l_{b}}-\phi \\
& { }_{b} \delta=\frac{\delta_{2}+\delta_{3}}{2}-\frac{\delta_{4}-\delta_{5}+\delta_{6}-\delta_{7}}{4} \\
& \phi=\frac{\delta_{8}-\delta_{9}+\delta_{10}-\delta_{11}}{2 \cdot h_{b}}
\end{aligned}
$$

ここで、 $Q$ は試験体に作用するせん断力、 $L_{n}$ は柱梁接合部中心 からジャッキ軸心までの距離、 $L$ は柱梁接合部中心から反力点側 のジャッキ材端ピン中心までの距離、 $\theta_{0}$ は柱梁接合部中心と反 力点側のジャッキ材端ピン中心を結ぶ直線の水平からの角度、 $\theta_{j}$ はジャッキの傾斜角、 $\delta_{1}$ はジャッキの鉛直変位、 $L_{j}$ はジャッキ端 ピン中心から鉛直変位計測点までの距離である。また、 $b \delta$ は加 力点の相対水平変位、 $\phi$ は柱梁接合部における柱フェイス面の回 転角、 $h_{b}$ は梁フランジ中心間距離である。

また、梁端におけるフランジとウェブの歪計測位置を図 5 に示す。 接合部近傍における梁フランジの平均軸歪と、梁ウェブが伝達する モーメントを計測するため、歪ゲージを貼付した。

\section{3. 実験結果}

\section{1 荷重-変形関係と破壊状況}

各試験体の荷重-変形関係については、梁端モーメント ${ }_{b} M$ と梁 の部材角 ${ }_{b} \theta$ をそれぞれ素材試験結果と実測板厚に基づき算定した 梁の全塑性モーメント ${ }_{b} M_{p}$ と全塑性モーメントに対応寸る梁の弾性 部材角 ${ }_{b} \theta_{p}$ で除した ${ }_{b} M / b M_{p}-{ }_{b} \theta / b \theta_{p}$ 関係として、図 6,7 に示寸。図 中には、素材試験結果と実測板厚に基づき算定した接合部の最大耐 力 ${ }_{j}^{11} M_{u}$ を接合部係数 $\alpha\left(={ }_{j} M_{u} /{ }_{b} M_{p}\right)$ として破線で示している。

試験体の終局状態であるが、ノンスカラップでエンドプレートに 接合された接合部係数が最も大きな試験体であり、局部座屈の発生 を抑えるためのスチフナを取り付けていない D-F については局部 座屈の発生により最大耐力が決まったが、残り 18 体については、 破断により最大耐力が決まった。破断により最大耐力が決まった試 験体について、後述する接合部の破断につながる延性亀裂の発生位 置と亀裂の進展状況の例を、図 8 ならびに図 9 に示す。

破断により最大耐力が決まったスカラップ有りの試験体では、い ずれもスカラップ底、梁フランジ中央部の溶接止端ならびに溶接始 終端部の溶接止端に延性亀裂の発生が確認された。これらの試験体 のうち、A-19、A-F、BH16-12、BH16-16、BH16-22、BH12-12、BH12-22、 C-150-9、C-200-12、C-200-9 は、スカラップ底に発生し進展した延 性亀裂を起点に破断した。BH12-16 は、スカラップ底の延性亀裂が ある程度は進展したが、最終的には梁フランジ中央部の溶接止端に 発生し進展した延性亀裂を起点に破断した。A-12、C-12、C-19 は、 梁フランジ溶接始終端部の溶接止端に生じた延性亀裂を起点に破断 した。破断で最大耐力が決まったスカラップ有りの試験体について は、スチフナの有無による破壊性状の違いは見られなかった。

一方、破断により最大耐力が決まったノンスカラップの試験体 B-12、B-19、D-12、D-19 では、いずれも梁フランジ中央部の溶接 止端ならびに溶接始終端部の溶接止端に延性亀裂の発生が確認され たが、最終的には梁フランジ溶接始終端部の溶接止端に生じた延性 亀裂を起点に破断した。これらの試験体の中で、局部座屈の発生を
抑えるためのスチフナを取り付けていない D-12,D-19 については、 わずかな局部座屈の発生が観察されたが、局部座屈が進展する前に 破断により最大耐力が決まった。

局部座屈により最大耐力が決まった D-F については、最大耐力 以降も全塑性モーメント程度の耐力を保ちつつ、安定した履歴を描 いた。D-F については振幅が $10 \theta_{p}$ に入る手前でジャッキのストロ ークが限界に達したため、その時点で載荷を終了した。なお、D-F においても溶接始終端部の溶接止端に延性亀裂の発生が確認されて いる。

\section{2 塑性変形能力}

各試験体が繰り返し荷重のもとで発揮した塑性変形能力を、式(7) で定義される累積塑性変形倍率 $\eta$ と、式(8)で定義される履歴曲線 から抽出した骨格曲線(定義を図 10 に示寸)における塑性変形倍率 ${ }_{s} \eta$ で表し、接合部係数 $\alpha$ との関係で図 11,12 に示す。また、実際の 設計では鋼材の規格強度に基づき接合部係数を評価することから、 鋼材の規格強度の下限值と公称板厚を用いて計算した接合部係数 $\alpha_{F}$ と $\eta$ ならびにs $\eta$ の関係を図 13,14 に示す。各試験体の $\eta$ と $n$ の 值は表 3 にも示す。

$$
\begin{gathered}
\eta=\Sigma_{b p} \theta / b \theta_{p} \\
{ }_{s} \eta=\sum_{b p} \theta_{s} / \theta_{p}
\end{gathered}
$$

ここで、 $\Sigma_{b p} \theta$ は最大耐力が決まり変形の進行に伴い荷重の低下 が開始する時点までの累積塑性変形(図 10)，， $\Sigma_{b p} \theta_{s}$ は骨格曲線に おける塑性変形(図 10)

図 11,12 には文献 3)に示される保有耐力接合の条件である $\alpha=1.2$ を実線で示す。いずれの図においても、保有耐力接合の条件である 1.2 を境に、接合部係数が保有耐力接合の条件を満たす範囲では接 合部係数が高くなるにつれ、接合部が最大耐力に至るまでの塑性化 領域の拡大に伴う塑性変形能力の向上が見られる。一方、保有耐力 接合の条件を満たさない範囲では、塑性変形能力は低い值に留まっ ている。また、保有耐力接合の条件である接合部係数が 1.2 程度で ある場合の塑性変形能力は、 $\eta$ で 20 程度、 $s \eta$ で 4 程度であった。 既報 のでの中層の梁降伏型平面骨組の弾塑性応答解析で得られた、 適切な強度分布の下で梁部材の破断に対する変形性能を骨格曲線と 対応する一方向荷重下における等価塑性変形倍率で 3 程度確保する ことで、塑性変形能力の高い部材によって構成される構造ランク I 》の梁降伏型骨組に対する要求エネルギー吸収能力を確保できると いう知見を踏まえると、文献 3)に示されている保有耐力接合の条 件である接合部係数 1.2 は、接合部の破断に至るまでの最低限の塑 性変形能力を確保し、骨組の耐震性能を確保する上で妥当な值であ ることを示す結果と言える。ここで、保有耐力接合の条件を満たさ ない接合部係数 $\alpha$ が 1.2 以下の範囲に注目寸ると、 $\alpha$ が 1.0 1.1 程 度の範囲では $\alpha$ が 1.0 を下回る場合も含め、 $\eta$ で $15 \sim 20$ 程度、 $s \eta$ で 2 〜 4 程度の值を示している。 $\alpha$ が 1.0 を下回る場合、接合部の最大 耐力が梁の全塑性モーメントを下回り計算上は塑性変形能力が全く 期待できないことになるが、実際には破断に至るまでに接合部近傍 の梁フランジが塑性変形することからある程度の塑性変形能力は存 在することになる。そのため、接合部係数が 1.0 をやや下回る領域 でも塑性変形能力が下限值的に存在寸る結果となった。 

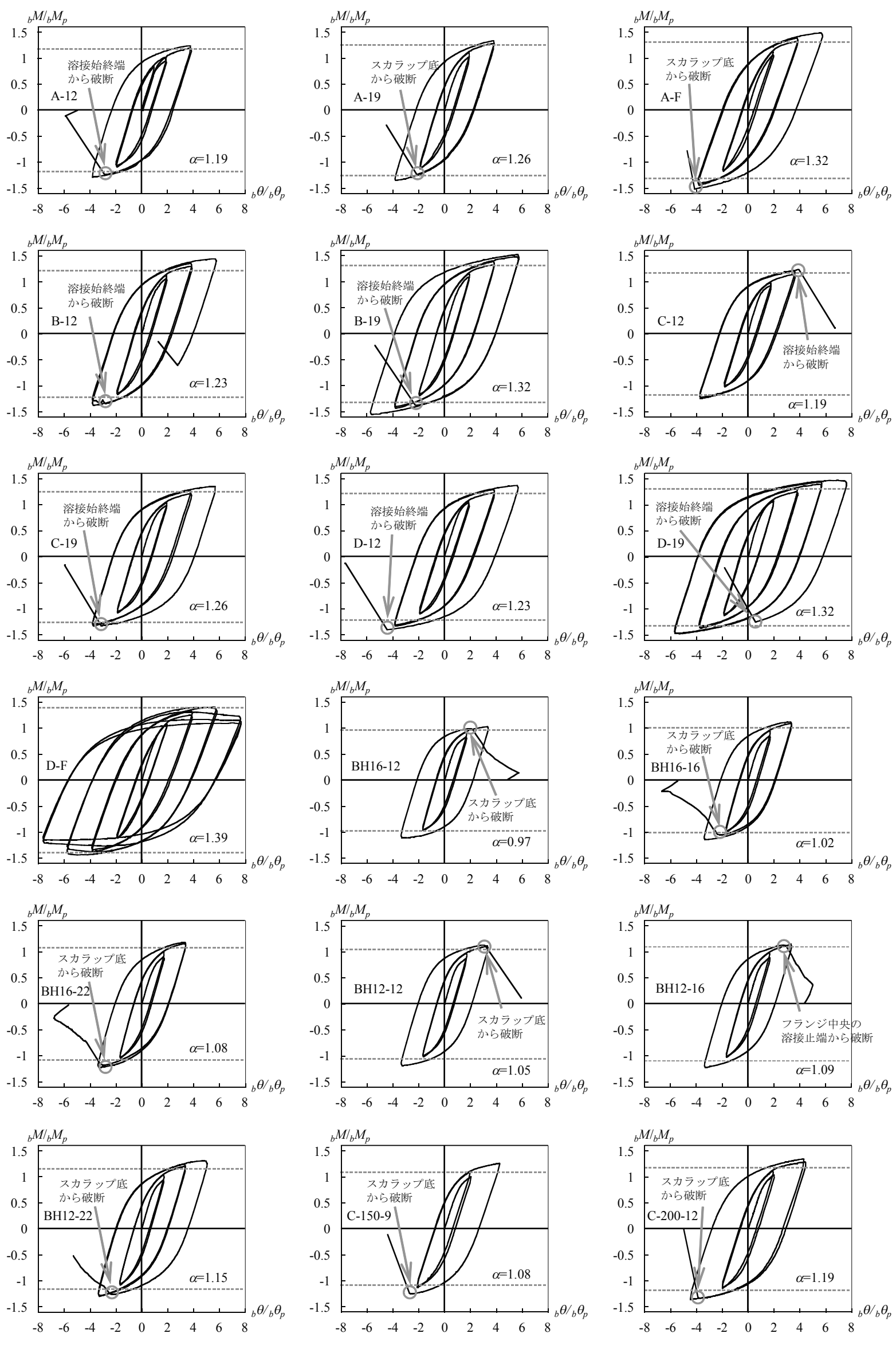

図6 荷重-変形関係1 


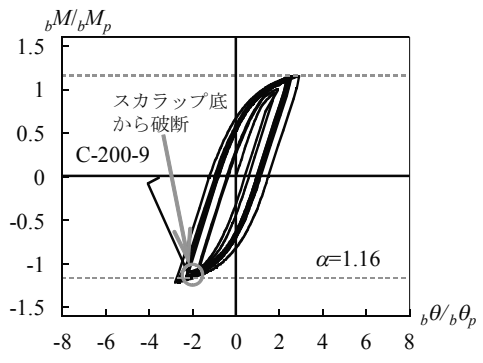

図7 荷重-変形関係2

表3 実験結果一覧

\begin{tabular}{c|c|c|c|c|c|c|c}
\hline No. & 試験体名 & $\eta$ & $s \eta$ & $\begin{array}{c}b M_{\max } \\
(\mathrm{kN} \cdot \mathrm{m})\end{array}$ & $\begin{array}{c}b M_{w \max } \\
(\mathrm{kN} \cdot \mathrm{m})\end{array}$ & $\begin{array}{c}b M_{p e} \\
(\mathrm{kN} \cdot \mathrm{m})\end{array}$ & $\begin{array}{c}b M_{y e} \\
(\mathrm{kN} \cdot \mathrm{m})\end{array}$ \\
\hline 1 & A-12 & 20.9 & 4.3 & 1266 & 202 & 831 & 798 \\
\hline 2 & A-19 & 19.2 & 3.8 & 1324 & 221 & 978 & 918 \\
\hline 3 & A-F & 28.9 & 4.9 & 1490 & 264 & 1108 & 1065 \\
\hline 4 & B-12 & 19.5 & 3.7 & 1351 & 273 & 1019 & 960 \\
\hline 5 & B-19 & 46.4 & 6.7 & 1521 & 350 & 1029 & 1006 \\
\hline 6 & C-12 & 24.6 & 4.5 & 1219 & - & 826 & 817 \\
\hline 7 & C-19 & 33.1 & 4.4 & 1303 & - & 893 & 873 \\
\hline 8 & D-12 & 32.7 & 5.8 & 1373 & - & 1025 & 953 \\
\hline 9 & D-19 & 63.4 & 7.0 & 1448 & - & 1021 & 955 \\
\hline 10 & D-F & 100.4 & 6.0 & 1409 & - & 1099 & 997 \\
\hline 11 & BH16-12 & 15.8 & 2.9 & 1184 & 135 & 902 & 815 \\
\hline 12 & BH16-16 & 20.2 & 3.9 & 1314 & 266 & 858 & 838 \\
\hline 13 & BH16-22 & 20.4 & 3.7 & 1407 & 296 & 973 & 907 \\
\hline 14 & BH12-12 & 16.1 & 3.4 & 1181 & - & 824 & 800 \\
\hline 15 & BH12-16 & 15.6 & 2.7 & 1188 & 160 & 846 & 790 \\
\hline 16 & BH12-22 & 30.5 & 3.6 & 1354 & 245 & 836 & 876 \\
\hline 17 & C-150-9 & 12.2 & 3.1 & 771 & 109 & 593 & 542 \\
\hline 18 & C-200-12 & 24.6 & 4.7 & 1020 & 139 & 777 & 689 \\
\hline 19 & C-200-9 & 30.9 & 2.6 & 914 & 108 & 711 & 665 \\
\hline
\end{tabular}

表中、 $\eta$ は累積塑性変形倍率(式(7))、 $s \eta$ は骨格曲線における塑性変 形倍率 $s \eta\left(\right.$ 式(8))、 ${ }_{b} M_{\text {max }}$ は梁の最大耐力、 ${ }_{b} M_{w \max }$ は梁ウェブにおけ る伝達モーメントの最大值、 ${ }_{b} M_{p e}$ は梁の全塑性耐力の実験值、 ${ }_{b} M_{y e}$ は梁の降伏耐力の実験值

また、梁フランジ溶接部の破壊状況の違いについては、スカラッ プの有無と併せ図 11,12 中にプロットを分けて示している。スカラ ップ無しの場合には接合部係数が高いことから塑性変形能力も高く なっているが、今回の実験の範囲においては、破壊状況の違いによ る塑性変形性能一の影響はみられなかった。

接合部係数を鋼材の規格強度に基づき求めた図 13,14 でも、図 11,12 と同様の傾向が見られるが、ばらつきは大きくなっている。 付録に示したように、接合部係数の計算では梁フランジの降伏比が 影響寸る。図 13,14 では、梁フランジの降伏比(素材試験結果)でプ ロットを分けて示している。また、素材試験結果を用いて求めた接 合部係数 $\alpha$ と引張強さおよび降伏点の規格下限值を用いて計算し た接合部係数 $\alpha_{F}$ の比較を図 15 に示寸。図 15 からは、梁フランジ の降伏比の違いが接合部係数に与える影響が明確に捉えられ、降伏 比が高い場合には規格下限值を用いて計算した場合より低くなるこ とがわかるが、図 13,14に示した塑性変形能力との関係においては 顕著な違いとはなっていない。

接合部係数と塑性変形能力の関係に関連して、接合部係数の異な る試験体(A-12,A-19,A-F ならびに BH16-12,BH16-22,BH12-22)につい
て、それぞれ同じ位置に貼付した歪ゲージで計測した、破断した側 の梁フランジにおける材端部の平均歪と累積部材角の関係を図 16 に例示する。いずれも接合部係数が大きくなるにつれて、同じ変形 レベルでの梁フランジの歪が小さくなっていることが確認できる。

\section{3 破断によって決まる最大耐力}

保有耐力接合の条件は、接合部の最大耐力の計算值 ${ }_{j} M u$ が梁の全 塑性耐力の計算值 ${ }_{b} M_{p}$ に対して、どの程度上回っているかを表す接 合部係数 $\alpha \quad\left(=j M_{u} / b M_{p}\right)$ で以て判定する。接合部設計指針に示される

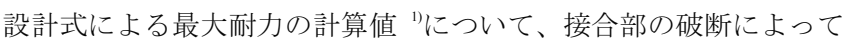
決まった試験体の最大耐力と比較し、設計式による予測結果の検討 を行う。

各試験体の最大耐力 ${ }_{b} M_{\text {max }}$ を表 3 に、接合部の破断によって決ま った試験体については実験值を計算值と比較し図 17 に示す。最大 耐力の実験值は、全体的に計算值よりも 1 割ほど高めの值となって おり、今回の実験の範囲では、接合部耐力の設計式 "が安全側の評 価となっていることがわかる。

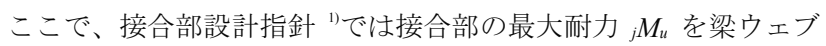
接合部の最大曲げ耐力 ${ }_{j} M_{w u}$ と梁フランジ接合部の最大曲げ耐力 ${ }_{j} M_{f u}$ の和として算定している。そこで、梁ウェブと梁フランジにおける 伝達モーメントの最大值について、実験值と計算值を比較検討する。

破断によって最大耐力が決まった各試験体について、梁ウェブに おける伝達モーメント ${ }_{b} M_{w}$ の最大值 ${ }_{b} M_{w \max }$ の值を表 3 に、接合部設 計指針 ${ }^{11}$ による計算值 ${ }_{j} M_{w u}$ との比較を図 18 に示す。ここで、実験 における梁ウェブにおける伝達モーメントの算定にあたっては、 (1) 梁ウェブに貼付した歪ゲージの計測值について、荷重-変形関係の 骨格曲線に対応する部分の歪増分をつなぎ合わせたものを一方向載 荷の場合に生じる歪と等価であると仮定し、(2)断面内の歪は計測区 間内を直線分布するものと仮定した。また、応力度-歪度関係につ いては、引張側については素材試験結果を、圧縮側については体積 一定の仮定の下で素材試験結果から求めた応力度-歪度関係を用い た。実験で得られた梁ウェブにおける伝達モーメントの最大值 ${ }_{b} M_{\text {wmax }}$ は、接合部設計指針 ${ }^{1)}$ にるる評価に対し、低いものでも同等、 高いものでは計算值の 7 割程度上回っており、接合部設計指針 ${ }^{11} に$ よる評価は全体的に安全側となっている。これは、接合部設計指針 による評価式が極限解析に基づくものであり、梁ウェブと柱スキン プレートにおける歪硬化を無視していることによると考えられる。

一方、 ${ }_{j} M_{f u}$ は片側の梁フランジの断面積 $A_{f}$ と梁フランジ中心間距 離 $d_{b}$ ならびに梁フランジ材の引張強さの積で与えられ、梁ウェブ におけるモーメント伝達効率に関わらず梁フランジが伝えることの できる曲げ応力の最大值を与えていると考えられる。最大耐力 ${ }_{b} M_{\max }$ から梁ウェブにおける伝達モーメントの最大值 ${ }_{b} M_{\text {wmax }}$ を引いたフラ ンジにおける伝達モーメントの最大值と梁フランジ接合部の最大曲 げ耐力 ${ }_{j} M_{f u}$ の比較を図 19 に示す。フランジの最大耐力も実験值は 計算値に対し低いものでも同等、高いものでは計算值の 2 割近く上 回っており、梁の最大耐力の実験值が計算值を上回った原因として、 ${ }_{j} M_{f u}$ についても梁端溶接部の拘束などによって計算值より上昇した ことが挙げられる。

\section{4 全塑性耐力および降伏耐力に関する検討}

梁ウェブにおけるモーメント伝達効率が低い場合、弾性域にお いても接合部における梁ウェブの負担モーメントが低下することか 
ら、全塑性耐力および降伏耐力も低下寸る。図 20 に実験で得られ た荷重-変形関係から抽出した骨格曲線を例示する。接合部係数が 小さくなると、荷重の低いところから塑性化が始まっており、鋼管 の板厚が厚い場合(BH16-22)よりも薄い場合(BH16-12)の方が、同じ

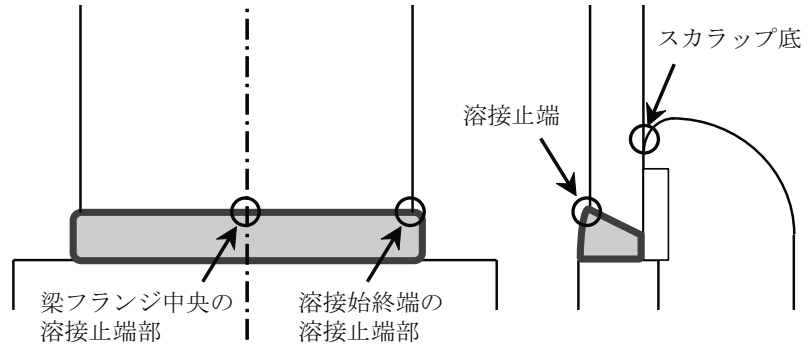

図8＼cjkstart梁フランジ端接合部における延性亀裂の発生位置

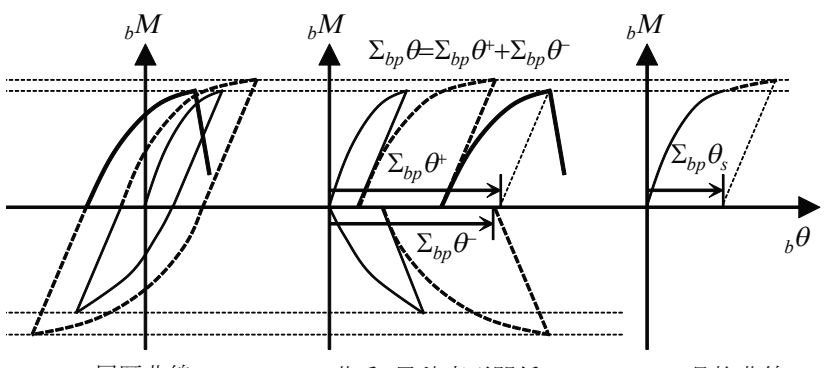

履歴曲線

骨格曲線
図10 骨格曲線の抽出

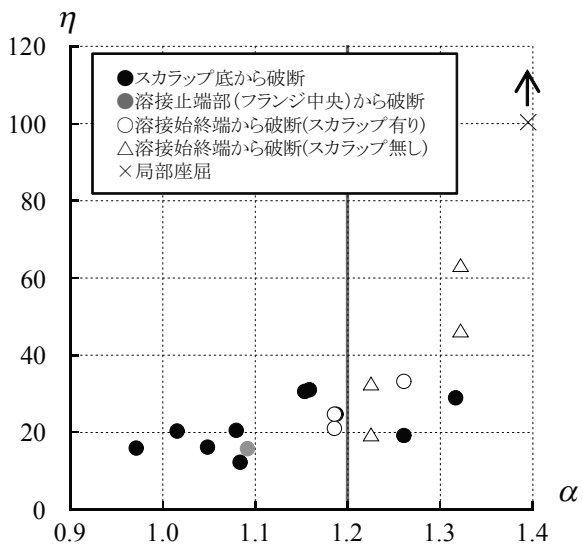

図11 累積塑性変形倍率 $\eta$ と 接合部係数 $\alpha$ の関係

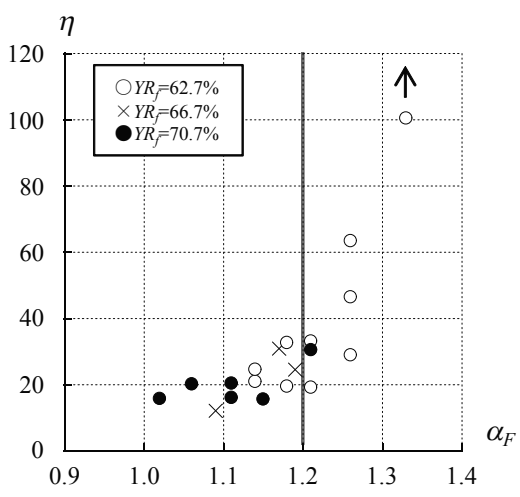

図13 $\eta-\alpha_{F}$ 関係
断面の組み合わせでもスカラップ無し(B-19)よりもスカラップ有り (A-19)のほうが、低い荷重で剛性が低下している。

本研究では、骨格曲線から全塑性耐力および降伏耐力の実験值を 求め、全塑性耐力および降伏耐力の計算值との関係を調べた。全塑

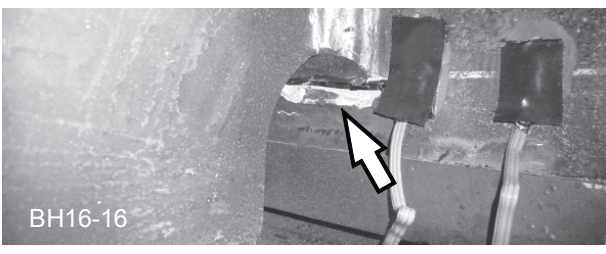

スカラップ底から延性亀裂が進展

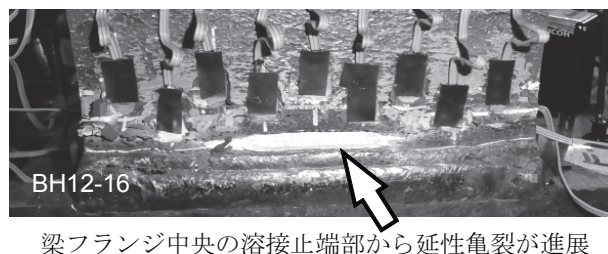

演端部から延性龟裂が進展

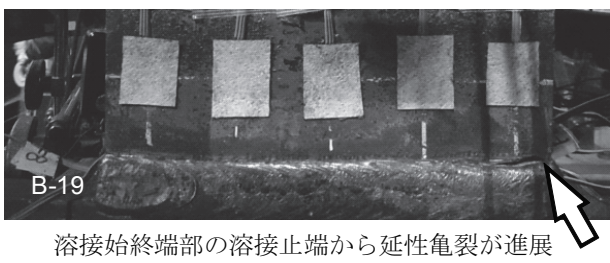

図9延性亀裂の進展状況

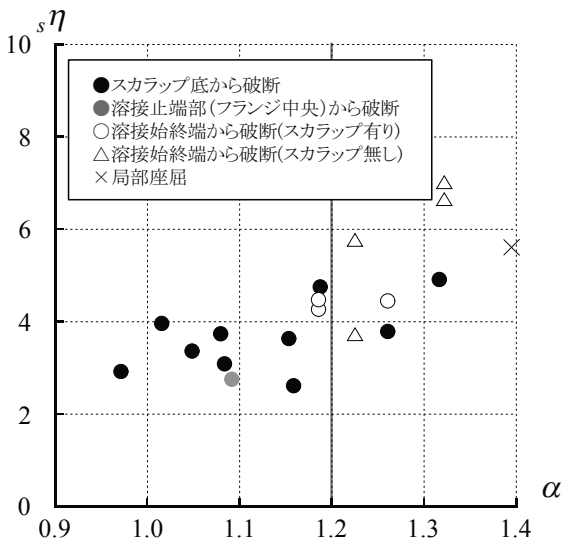

図12 骨格曲線における塑性変形倍率 $s \eta$ と接合部係数 $\alpha$ の関係

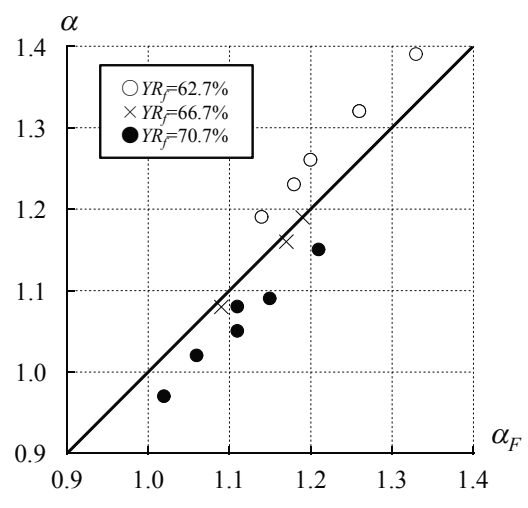

図15 $\alpha-\alpha_{F}$ 関係 

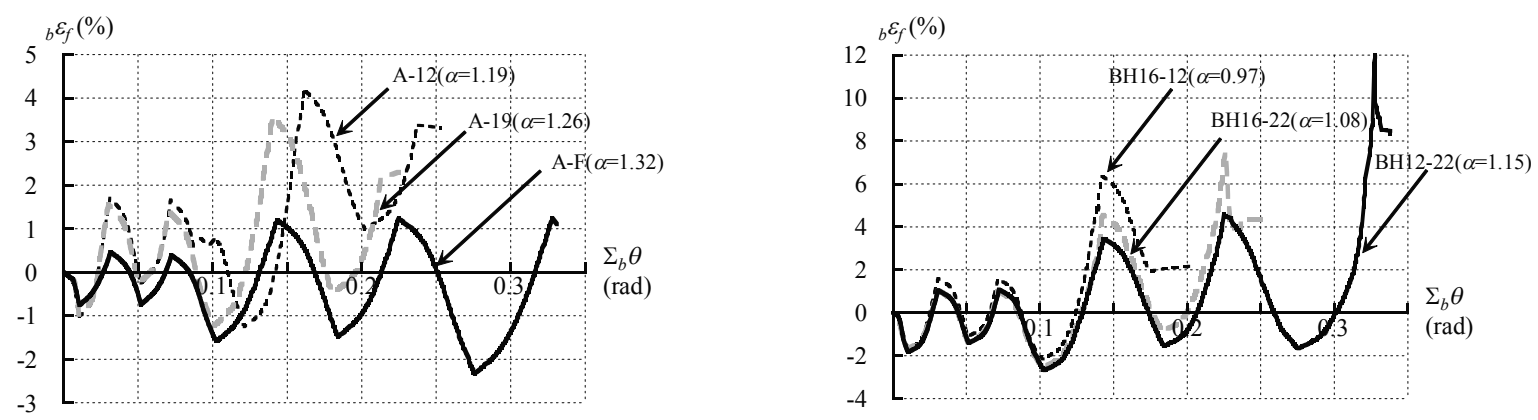

図16 梁フランジの平均歪と累積部材角の関係

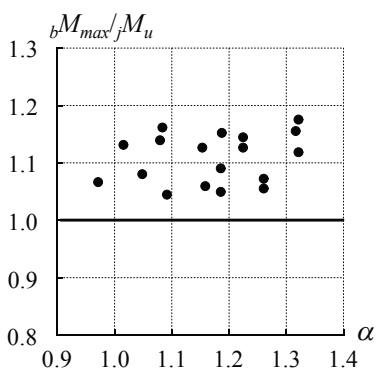

図17 最大耐力の実験值と計算値 の比較(破断で最大耐カが決まっ た試験体)
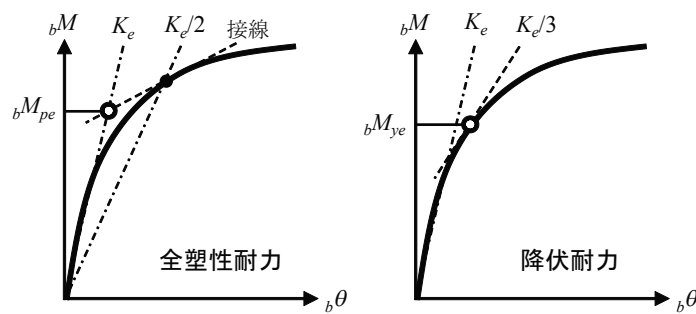

図2
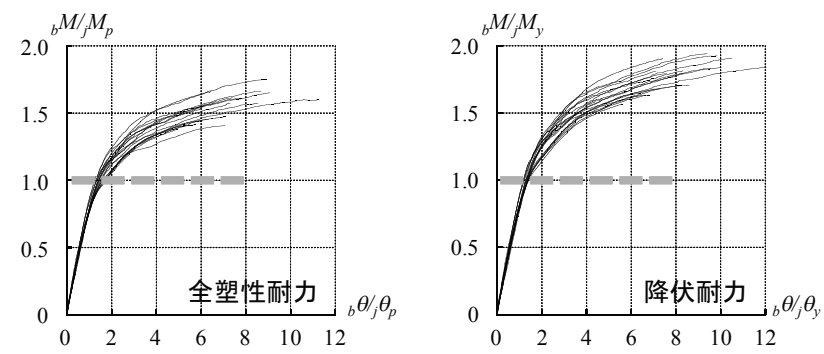

図24 ${ }_{j} M_{p}$ で基準化した骨格曲線

図25 ${ }_{j} M_{y}$ で基準化した骨格曲線

性耐力の実験值は、図 21 に示すように、文献 8)における検討結果 を踏まえ、初期剛性の $1 / 2$ の剛性線と骨格曲線の交点を求め、この 点における接線と初期剛性線との交点の荷重として求めた。また、 降伏耐力の実験值 ${ }_{b} M_{y e}$ については、接線剛性が弾性剛性の $1 / 3$ に低 下した点として求めた。

全塑性耐力および降伏耐力の実験值を表 3 に示す。また、計算値 との対応をそれぞれ図 22,23 に示す。ここで、全塑性耐力および降 伏耐力の計算值は以下のように求めた。まず、接合部における全塑 性耐力 ${ }_{j} M_{p}$ は、接合部設計指針 "质されるモーメント伝達効率の

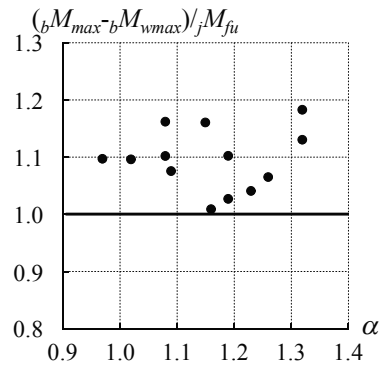

図19 梁フランジの最大耐カの実

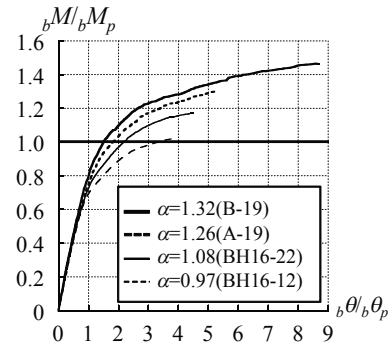

図20骨格曲線の比較

耐力が決まった試験体)
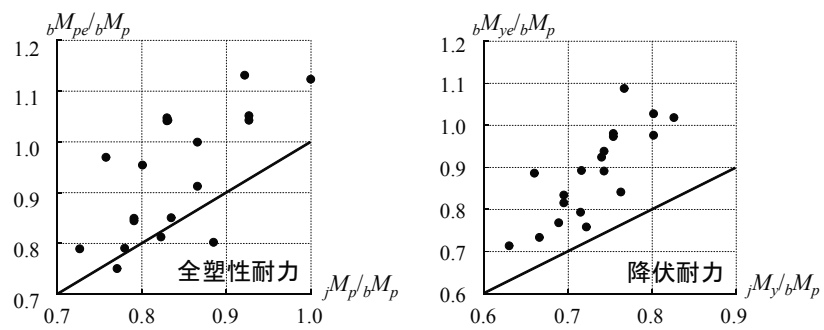

図22 ${ }_{b} M_{p e} / b M_{p}-{ }_{j} M_{p} / b M_{p}$ 関係

図23 ${ }_{b} M_{y e} /{ }_{b} M_{p}-j M_{y} / b M_{p}$ 関係
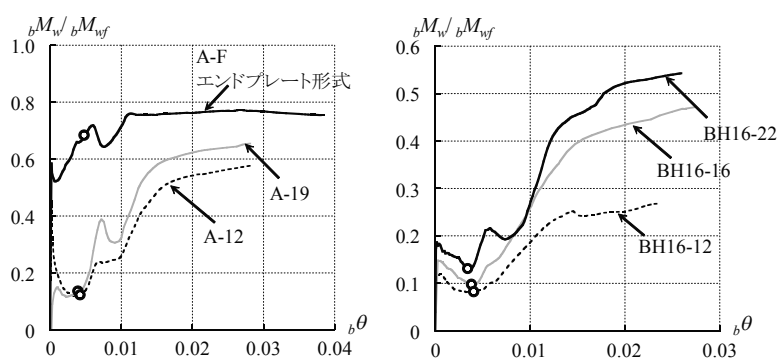

図26 ${ }_{b} M_{w} / b M_{w f}-{ }_{b} \theta$ 関係

低下を考慮した有効断面が全塑性耐力時においても同様であると仮 定し、(9)式より算出した。また、接合部における降伏耐力 ${ }_{j} M_{y}$ は、 接合部設計指針 ${ }^{1}$ に示される有効断面係数 ${ }_{j} Z_{e}$ を用いて(10)式より算 出した。全塑性耐力と降伏耐力のいずれについても、計算值は実験 值と同様の傾向ではあるがやや低めの值であり、下限值程度となっ ている。

$$
\begin{aligned}
& { }_{j} M_{p}=Z_{f p} \cdot \sigma_{y f}+m \cdot Z_{w p e} \cdot \sigma_{y w} \\
& { }_{j} M_{y}={ }_{j} Z_{e} \cdot \sigma_{y f}
\end{aligned}
$$


ここで、 $Z_{f p}$ は梁フランジの塑性断面係数， $Z_{w p e}$ はスカラップによ る断面欠損を考慮した梁ウェブの塑性断面係数、 $\sigma_{y f}$ は梁フラン ジの降伏点、 $\sigma_{y w}$ は梁ウェブの降伏点

また、 ${ }_{b} M$ と ${ }_{b} \theta$ をそれぞれ $M_{p}$ と ${ }_{j} M_{p}$ に達した時の弾性変形角 ${ }_{j} \theta_{p}$ で基準化した骨格曲線を図 24 に、 ${ }_{b} M$ と ${ }_{b} \theta$ をそれぞれ ${ }_{j} M_{y}$ と ${ }_{j} M_{y}$ に 達した時の弾性変形角 ${ }_{j} \theta_{y}$ で基準化した骨格曲線を図 25 に示す。降 伏耐力ならびに全塑性耐力の計算值 ${ }_{j} M_{y},{ }_{j} M_{p}$ は実験值に対して低 めの值ではあったが、 ${ }_{j} M_{y}$ に達したあたりで概初弾性限界に達し、 ${ }_{j} M_{p}$ に達したあたりから梁の塑性変形が進行していることがわかる。

ここで、弾性域から塑性域に達し最大耐力に至るまでの、梁ウェ ブにおけるモーメント伝達効率の推移を確認しておく。確認にあた り、上下梁フランジの歪を直線で結んだ、平面保持条件下での歪分 布から算出した全断面有効とした梁ウェブのモーメント ${ }_{b} M_{w f}$ を、 モーメント伝達効率が完全な場合の梁ウェブの伝達モーメントと仮 定した。梁ウェブにおける伝達モーメントの実験值 ${ }_{b} M_{w}$ を ${ }_{b} M_{w f}$ で 除したものを、骨格曲線における梁の部材角との関係で図 26 に例 示する。図中の○は梁フランジの歪が降伏歪に達する時点を示して いる。断面が平面保持されていると考えられるエンドプレートに接 合された試験体(A-F)では ${ }_{b} M_{w} / b M_{w f}$ は概ね一定の值となっているが、 角形鋼管に接合された試験体では、梁フランジが降伏歪に達したあ たりから ${ }_{b} M_{w} / M_{w f}$ が増加していることがわかる。

\section{4. 結}

梁を SN490、柱を BCR295 とした角形鋼管柱-H 形鋼梁接合部に ついて、特に梁ウェブにおけるモーメント伝達効率が低く接合部係 数が低くなり保有耐力接合の条件を満足しないような場合に、実際 にはどの程度の塑性変形能力があるのかを明らかにするため、これ まであまり行われてこなかった梁ウェブにおけるモーメント伝達効 率が低い接合部試験体を対象とした繰り返し載荷実験を行った。使 用した試験体は 19 体、接合部係数の範囲は $0.97 \sim 1.39$ であり、接 合部係数が最も大きな試験体であるノンスカラップでエンドプレー 卜に接合された 1 体を除き、接合部における破断により最大耐力が 決まった。本研究で得られた主な知見を以下にまとめる。

1.各試験体が繰り返し荷重のもとで発揮した塑性変形能力を、接合 部係数との関係で整理したところ、SN490による梁を用いた場合の 梁端接合部の保有耐力接合の条件 ${ }^{3)}$ として示されている接合部係数 1.2 程度を境に、接合部係数が保有耐力接合の条件を満たす範囲で は接合部係数が高くなるにつれ塑性変形能力の向上が見られる一方 で、保有耐力接合の条件を満たさない範囲では、塑性変形能力は低 い值に留まっていることを確認した。また、保有耐力接合の条件で ある接合部係数が 1.2 である場合は、塑性変形能力は高くはないも のの、骨組の耐震性能を確保する上では最低限の能力を確保してい るものと考えられる。保有耐力接合の条件として 1.2 の接合部係数 を確保することは、接合部の破断に至るまでの最低限の塑性変形能 力を確保する上で妥当であると考えられる。

2. 保有耐力接合の条件を満たさない、接合部係数が 1.2 以下となる 範囲では、接合部係数の低下に伴い塑性変形能力は低くなるものの、 塑性変形能力の低下の程度は緩やかであり、接合部係数が 0.97 と
1.0 を下回る場合も含め、下限值的にある程度の塑性変形能力を有 することを確認した。接合部係数が 1.0 を下回る場合には、接合部 の最大耐力が梁の全塑性モーメントを下回り、計算上は塑性変形能 力が全く期待できないことになるが、実際には接合部近傍において、 全強接合された梁フランジが破断に至るまでに塑性変形することに よる。

3. 保有耐力接合の条件を検討する際に用いる接合部の最大耐力の計 算值 ${ }^{1}$ について、接合部の破断によって決まった試験体の最大耐力 と比較したところ、最大耐力の実験值は全体的に計算值よりも 1 割 ほど高めの值となっており、今回の実験の範囲では、接合部耐力の 設計式”が安全側の評価となっていることを確認した。

4.接合部の最大耐力は梁フランジ接合部の最大曲げ耐力 ${ }_{j} M_{f u}$ と梁ウ

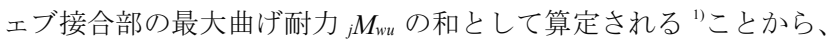
梁ウェブにおけるモーメント伝達効率に関わる、接合部設計指針に よる ${ }_{j} M_{w u}$ の計算值と破断によって最大耐力が決まった各試験体の 梁ウェブにおける伝達モーメント ${ }_{b} M_{w}$ の最大值 ${ }_{b} M_{w \text { max }}$ を比較したと ころ、実験值は計算值に比べ低いものでも同等、高いものでは計算

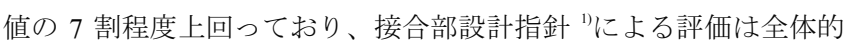
に安全側となっていることを確認した。これは、接合部設計指針に よる評価式が極限解析に基づくものであり、梁ウェブと柱スキンプ レートにおける歪硬化を無視していることによると考えられる。ま た、フランジについても最大耐力の実験值は計算值に対し低いもの でも同等、高いものでは計算值の 2 割近く上回っていることを確認 した。

\section{謝辞}

本研究における実験は、平成 23 25 年度国土交通省建築基準整 備促進事業において実施されたものである。実験の実施にあたって は、納所昌広君はじめ、東京工業大学大学院生諸氏の協力を得た。 ここに記して謝意を表す。

\section{参考文献}

1) 日本建築学会 : 鋼構造接合部設計指針 第 3 版, 2012.3

2) 日本建築学会 : 溶接接合設計施工ガイドブック，2008.11

3) 建築物の構造関係技術基準解説書編集委員会 : 2007 年版建築物の構造関 係技術基準解説書，全国官報販売協同組合

4) 三木徳人, 山田 哲, 吉敷祥一, 焦 瑜, 長谷川 隆 : 角形鋼管柱 $-\mathrm{H}$ 形鋼 梁偏心接合部の力学挙動, 日本建築学会構造系論文集, 第 80 巻 第 710 号, pp.669-679, 2015.4

5) (独)建築研究所, (社) 日本鉄鋼連盟: 鋼構造建築物の構造性能評価試験法 に関する研究委員会報告書, 2002

6) 山田 哲, 松本由香 : 梁部材の終局挙動が鋼構造多層骨組の耐震性能に与 える影響, 日本建築学会構造系論文集 第 535 号, pp.133-140, 2000.9

7) 日本建築学会 : 建築耐震設計における保有耐力と変形性能(1990), 1990

8) 島田侑子, 吉敷祥一, 山田哲 : 実験結果に基づく全塑性モーメントの評価 方法に関する考察, 2008 年度日本建築学会関東支部研究報告集, pp.305-308, 2009.3

\section{付録1 既往の実験で扱われた試験体の接合部係数}

梁フランジの破断により最大耐力が決まった既往の実験付 ${ }^{1)-1}{ }^{11}$ について、 試験体の接合部係数を調べた。調査の対象とした実験は、使用鋼材(梁)が、 $400 \mathrm{~N}$ 級あるいは 490N 級(SN490、SN400、SM490、SS400)で、工場接合形式の接 合であり、JASS6 の改良型スカラップまたはノンスカラップ形式の接合部詳 細となっている試験体を用いたもので、漸増変位振幅繰り返し載荷が行われ たものである。試験体の終局状態としては、梁フランジが延性亀裂から破断 
したと判断できたものを対象とし、溶接不良等による早期の脆性破断を扱っ た実験は除いた。扱われた試験体の接合部係数と、接合部の最大耐力の実験 值の関係を付図 1 亿示寸。縦軸は、破断した側の荷重領域での梁の最大耐力 の実験值(絶対值) $b_{\text {m max }}$ を梁の全塑性耐力の計算值 $b M_{p}$ で除した值であり、横 軸は接合部設計指針による接合部の最大耐力の計算値 ${ }_{j} M_{u}$ を梁の全塑性耐力 の計算値 ${ }_{b} M_{p}$ で除した值である接合部係数 $\alpha$ である。図中には本論文で行っ た実験も○でプロットしている。でプロットした既往の実験は、接合部係 数が 1.11 1.52 の範囲で行われているが、1.2 を下回る領域での実験結果が極 めて少ないことがわかる。また、既往の実験においても、本研究における実 験結果同様、最大耐力の実験值は全体的什計算值よりも高くなっており、接 合部耐力の設計式 ${ }^{1)}$ は最大耐力の下限值を捉えていると言える。

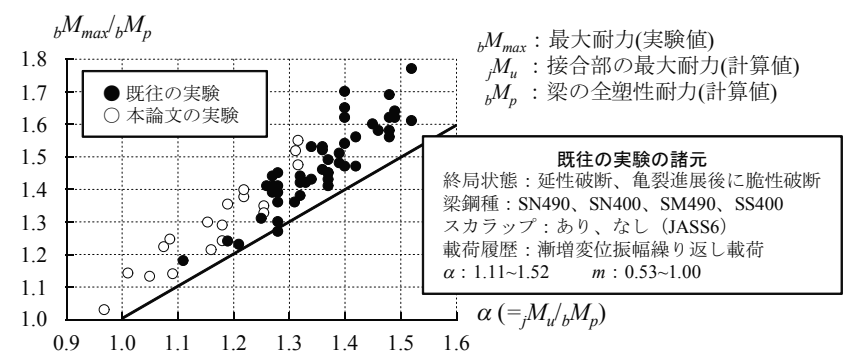

付図 1 既往の実験付 1 )-付 11 )

\section{参考文献}

付 1) 石井匠，菊川春三，森田耕次，高梨晃一：通しダイアフラム形式・柱 梁接合部の破断性状に関寸る実験的研究，日本鋼構造協会鋼構造論文集 6(24), 87-102, 1999

付 2) 山本昇, 石井匠, 森田耕次 : はり端溶接接合部の力学的挙動におよぼ すスカラップの影響，構造工学論文集. B 39B，493-506， 1993.3

付 3) 皿海康行, 斎藤英明, 横山治男, 青柳隆之 坂本真一, 田沼良一: 梁端 ディテールの違いが角形鋼管柱-H 形断面梁接合部における梁端仕口部の 構造性能に及ぼす影響 梁全体の曲げ性能に占める梁フランジの割合いが 比較的小さい場合, 日本建築学会大会学術講演梗概集, pp.373-374, 1998.7

付 4) 川乗安生，甲津功夫：現場接合形式柱梁溶接接合部の力学性状に関す る研究 その 1 エンドタブと溶接ワイヤ材質の影響，鋼構造論文集，第 7 巻 第 28 号, pp.71-85, 2000.12

付 5) 甲津功夫，中田智三：現場接合形式柱梁溶接接合部の力学性状に関す る研究 その 2 開先形状と溶接ワイヤの影響, 鋼構造論文集, 第 10 巻第 38 号，pp.1-15，2003.6

付 6) 中込忠男, 的場耕, 岩田衛: 梁材の力学的性能が柱梁溶接接合部の変 形能力に与える影響に関する実験的研究, 日本建築学会構造系論文集, 第 540 号, pp.111-117，2001.2

付 7) 久世庸平, 中込忠男, 市川祐一, 服部和徳, 杉江篤司, 村井正敏 : , ン裏当て金工法を用いた接合部ディテールが柱梁溶接接合部の変形能力に 与える影響に関寸る実験的研究日本建築学会北陸支部研究報告集 (45), $33-36,2002.6$

付 8) 焦瑜, 角野大介, 島田侑子, 吉敷祥一, 山田哲 : 繰り返し荷重を受け る梁部材のエネルギー吸収能力その 2 実験の結果と考察, 日本建築学会 大会学術講演梗概集，pp.569-570，2008.7

付 9) 中込忠男, 藤田哲也, 南圭祐, 李建, 村井正敏 : 柱梁溶接接合部にお けるノンスカラップ工法梁端ディテールに関する実験的研究, 日本建築学 会構造系論文集，第 498 号, pp.145-151，1997.8

付 10) 中込忠男, 山田丈富, 村井正敏, 的場耕, 會田和広：ノンスカラップ 工法における梁端ディテールが柱梁溶接接合部の変形能力に及ぼす影響に 関する実験的研究, 日本建築学会構造系論文集, 第 546 号, pp.121-128, 2001.8

付 11) 吹田啓一郎：鋼構造ラーメン骨組の耐震設計における梁端接合部の耐 力要求值, 日本建築学会構造系論文集, 第 567 号, pp.165-171, 2003.5

\section{付録2 鋼材の降伏比が接合部係数に与える影響}

角形鋼管柱に接合される梁端接合部の接合部係数 $\alpha$ は、接合部の最大耐力 ${ }_{j} M_{u}$ の梁断面の全塑性耐力 ${ }_{b} M_{p}$ に対する比であり、接合部設計指針 ${ }^{1}$ による ${ }_{j} M_{u}$ の算定式と、フィレット部を無視した ${ }_{b} M_{p}$ の算定式から、式(付 1)、(付 2)に より求めることができる。式(付 1)から、接合部係数 $\alpha$ は、梁フランジおよ び梁ウェブの全塑性耐力と、梁フランジの降伏比 $Y R_{\text {f }}$ 梁ウェブ接合部の無 次元化耐力 ${ }^{11} m$ 、梁ウェブの高さ $d_{w}$ およびスカラップの高さ $S$ r で決まること がわかる。
梁断面を H-600×200×11×17(SN490B)としたときの梁フランジの降伏比と接 合部係数 $\alpha$ の関係を、スカラップの有無ごとに付図 2 に示す。ここで、梁ウ ェブの降伏点は梁フランジと同じとした。図中の網掛け部分は、統計調査 ${ }^{\text {(12) }}$ による $\mathrm{H}$ 形鋼(SN490B)における降伏比の平均值士標準偏差の範囲を、灰色の 破線は設計值である降伏点の規格下限值 $F$ と引張強さの規格下限值 $F_{u}$ の比 $F / F_{u}$ を表す。実際の鋼材の降伏比は $F / F u$ より高くなる場合が多いこと、降伏 比が高くなると接合部係数 $\alpha$ が低下し、統計調査に基づく平均值士標準偏差 の範囲では設計值での想定より $0.1 \sim 0.15$ 程度低下する。

また、梁ウェブ接合部の無次元化耐力 $m$ が小さくなると接合部係数 $\alpha$ も小 さくなる。 $m$ は柱、梁の断面寸法と、柱と梁ウェブの降伏点の比で決まる。 梁断面を H-600×200×11×17(SN490B)、柱断面を $\square-400 \times 400 \times 12$ もしは 19 と した場合の、梁ウェブの降伏点に対する柱の降伏点の比 $\sigma_{v} / \sigma_{v w}$ と $m$ 及び $\alpha$ の関係を付図 3 に示寸。図中の網掛け部分は統計調査 ${ }^{(12)}$ に基づく $\mathrm{H}$ 形鋼 (SN490B)における降伏点の平均值士標準偏差と、角形鋼管(BCR295)における 降伏点の平均值干標準偏差の組み合わせの範囲を、灰色の破線は設計值であ る BCR295 と SN490B の降伏点の規格下限值 $F$ の比を示す。実際の鋼材の降 伏点の比は、設計值である BCR295 と SN490B の降伏点の規格下限值 $F$ の比 に比べ高くなる場合が多く、 $m$ 及び $\alpha$ は設計值に比べて高くなる場合が多い が、接合部係数への影響は梁フランジの降伏比の変動に比べると小さい。

$$
\begin{aligned}
\alpha & =\frac{{ }_{j} M_{u}}{{ }_{b} M_{p}} \\
= & \frac{B \cdot t_{f} \cdot\left(D_{b}-t_{f}\right) \cdot \sigma_{u f}+m \cdot \frac{1}{4}\left(D_{b}-2 t_{f}-2 S_{r}\right)^{2} \cdot t_{w} \cdot \sigma_{y w}}{B \cdot t_{f} \cdot\left(D_{b}-t_{f}\right) \cdot \sigma_{y f}+\frac{1}{4}\left(D_{b}-2 t_{f}\right)^{2} \cdot t_{w} \cdot \sigma_{y w}} \\
= & \frac{\frac{1}{Y R_{f}} \cdot{ }_{b} M_{f p}+m \cdot\left(1-2 \frac{S_{r}}{d_{w}}\right)^{2}{ }_{b} M_{w p}}{{ }_{b} M_{f p}+{ }_{b} M_{w p}} \\
m & =\min \left\{1,4 \frac{t_{c}}{d_{j}} \sqrt{\frac{b_{j} \cdot \sigma_{y c}}{t_{w} \cdot \sigma_{y w}}}\right\}
\end{aligned}
$$

ここで、 $\sigma_{u f}$ は梁フランジの引張強さ、 $\sigma_{u f}$ は梁ウェブの引張強さ、 $\sigma_{v c}$ は柱 の降伏点、 $\sigma_{u}$ は柱の引張強さ、他の記号は接合部設計指針 ${ }^{1}$ による
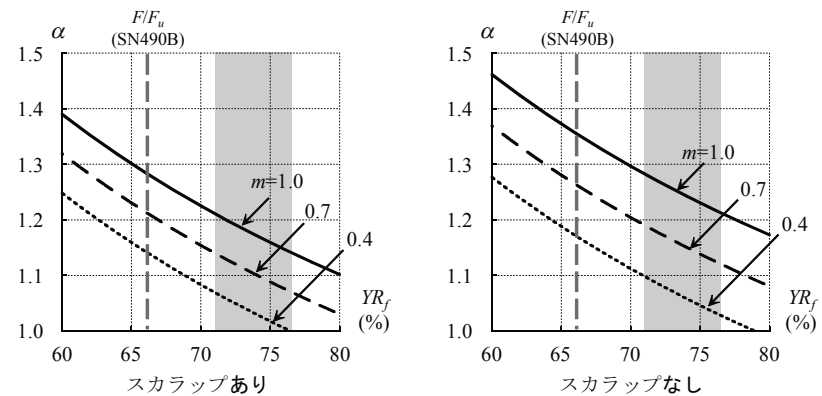

付図2 梁フランジの降伏比 $Y R_{f}$ と接合部係数 $\alpha$ の関係
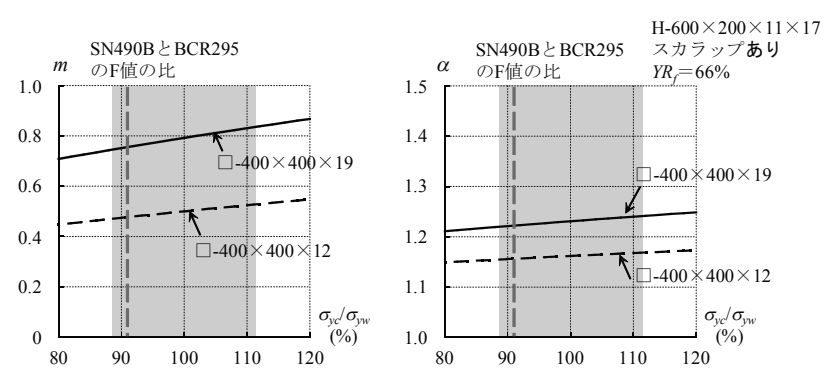

付図3 柱と梁ウェブの降伏点の比が梁ウェブの接合部の無次元化耐力 $m$ と 接合部係数 $\alpha$ に及ぼす影響

\section{参考文献}

付 12) 藤澤一善,杉本真隆,一戸康生, 園田正雄 : SN 鋼の機械的性質 - 化学成分 に関する統計調査,学術講演梗概集,pp.699-700, 2013.08 


\title{
CYCLIC LOADING TEST OF BEAM-TO-COLUMN CONNECTION WITH LOW MOMENT TRANSFERRING EFFICIENCY IN WEB
}

\author{
Satoshi YAMADA ${ }^{* 1}$, Norihito MIKI ${ }^{* 2}$, Shoichi KISHIKI ${ }^{* 3}$, \\ Takashi HASEGAWA ${ }^{* 4}$ and Yu JIAO*5 \\ ${ }^{* 1}$ Prof., Structural Engineering Research Center, Tokyo Tech., Dr.Eng. \\ ${ }^{* 2}$ Grad. Stud. Tokyo Tech., M.Eng. \\ ${ }^{* 3}$ Assoc. Prof., Structural Engineering Research Center, Tokyo Tech., Dr.Eng. \\ ${ }^{*} 4$ Senior Researcher, Structural Engineering Dept., Building Research Institute, Dr.Eng. \\ ${ }^{*}$ Assist. Prof., Dept. of Architecture, Tokyo Univ. of Science, Dr.Eng.
}

Joint efficiency of beam web affects the strength and plastic deformation capacity of wide flange beam to RHS column connections. When thin-walled sections are used as columns, joint efficiency is lower due to insufficient strength and out-of-plane stiffness of the skin plate. Joint coefficient of a connection is defined as the ratio of the maximum strength of the connection to the full plastic strength of its beam, where the former is calculated considering the web's joint efficiency. The Building Design Law provides that joint coefficient should be larger than 1.2 when SN490 steel is used in the beam to guarantee enough strength of the connection in order to ensure plastic deformation capacity of beam. While in the "Recommendation for Design of Connections in Steel Structures", this critical value is 1.25 . Apparently, some of the qualified connections based on the Building Design Law might not have enough strength according to the "Recommendation for Design of Connections in Steel Structures". Furthermore, the "Guidebook on Design and Fabrication of Welded Connections" states that when SN490 wide-flange beam is connected to BCR295 RHS column, especially when the joint efficiency at beam web is low, there is a high possibility that the connection does not meet the criteria of connection strength. The plastic deformation capacity of these connections are not clear, a comprehensive evaluation is necessary.

Nineteen beam-to-column specimens with joint coefficients ranged from 0.97 to 1.39 were tested under incremental cyclic loadings. The plastic deformation capacity, maximum strength, yield strength and full plastic strength of the specimens with different failure modes were evaluated quantitatively. The main findings from the test results are as follows:

(1) 18 specimens ended up with ductile fracture at the beam-end flange during cyclic loadings. The other specimen of which the beam was welded onto the end-plate without weld access holes reached its ultimate status due to local buckling.

(2) Specimens with higher joint coefficients showed better plastic deformation capacities than those with lower joint coefficients. For the specimens with joint coefficients around 1.2, although the plastic deformation capacities are not particularly good, these specimens reached the minimum requirements of seismic design.

(3) For the specimens with joint coefficients lower than 1.2, plastic deformation capacities dropped slowly with the decrease of joint coefficients. Even the specimens with joint coefficients less than 1.0, of which the maximum strength of the connections were smaller than the full plastic moments of beams, showed certain plastic deformation capacities that still met the minimum requirements.

(4) The experimental values of the maximum strength of the specimens were about $10 \%$ higher than the calculated results based on the calculation approach suggested in the "Recommendation for Design of Connections in Steel Structures", which indicates that the "Recommendation for Design of Connections in Steel Structures" provides accurate evaluation of the maximum strength of beam-to-column connections on the safe side.

(5) For the specimens with lower joint efficiencies, the experimental values of maximum bending strength of beam web matched the calculated value based on the "Recommendation for Design of Connections in Steel Structures" well. For the specimens with good joint efficiencies, the experimental results were about $20 \%$ higher than the calculated results. The evaluation method is effective and also on the safe side. 